\title{
Word from an IFLA fox: an interview with Else Granheim
}

\section{Frances Laverne Carroll}

\section{INTRODUCTION}

Else Granheim was the first - and so far, the only - woman President of the International Federation of Library Associations and Institutions (IFLA), and is now Director General of the Statens bibliotektilsyn (Norwegian Directorate for Public and School Libraries) in Oslo, Norway. During an interview which took piace during the 55 th Council and General Conference of IFLA in Stockholm, on 23 August, 1990. Ms Granheim was asked to comment on her experience as President, in part with the aim of encouraging other women to advance in IFLA by following her example.

C: The first question involves you and how you became President of IFLA. You were its first and only woman president?

G: Yes.

C: Where did Else Granheim come from in the ranks of IFLA?

G: I started in the early 1960 s as a corresponding member to the committee on library buildings because I was dealing with library buildings and planning for many years. I was called an expert on that in Norway.

C: What personal and professional attributes have been most helpful to you in your career in relation to IFLA?

G: I have often wondered why I have engaged myself in international work and think it has something to do with an inborn curiosity. I have always been curious to see what is on the other side of the fence. Also, as a teenager during the Second World War in an occupied country, like others, I felt closed in. Our radios were confiscated and the official newspapers were only bringing censored news. We had to trust information from underground sources and listen illegally to radio bringing news from London. When peace came in 1945, I think Norwegian youth didn't know where to start to catch up for those lost years. Looking back, I can see now that this was a reason, an important reason, for wanting and seeing the necessity for, and the positive aspects of, getting outside and getting international contacts. Five years in your teenage period is a long time.

C: For how many years have you been connected with IFLA?

$G$ : After being a corresponding member to the committee on library buildings, I started attending IFLA conferences, taking a special interest in public library matters. The first one I attended took place in 1968 .

C: Was that in Frankfurt?

G: That was Frankfurt. One of the reasons why I remember it is because it was at the time when the Soviets went into Czechoslovakia, and I was standing among colleagues from East European countries when this news was brought to us. One of the great things at this year's conference has therefore been to meet these people again, people I have not seen for twenty-two years. It was very nice, especially for one colleague that 1 have been looking forward to meeting again for many years, that 1 recognized him after twentytwo years. That was in 1968, and so I have attended about twenty IFLA conferences.

C: Did your activities in IFLA from then on go in a direct line, moving you up a ladder, or were you in a variety of activities?

G: I was a member of the Standing Committee of the public library section, but I do not think that was the reason for my coming to the top in IFLA. I think it may have been what I did in 1975 as a local organizer of the IFLA conference in Oslo. Being in charge, at that time, made me known to the IFLA community. I had also, for many years, worked in close relationship with all the Nordic countries, as we have a lot in common, and also with the library community of the United Kingdom, at Anglo-Scandinavian public library conferences taking place every third year. I have taken it step by step, but from the late 1970s, I have been mainly involved with IFLA and partly with Unesco.

C: Did you want the office of president? Was it a surprise to you to be elected?

G: I was surprised at the moment when one of the other Executive Board members said to me that he wanted me to become the next president. because quite frankly I had not thought of it. When at first it was mentioned, and I heard it from several quarters, I said to myself, 'Well, why not? It is a challenge.' And why not, indeed? Wasn't it time to have a woman president in a profession where there are so many women? Also, I had been on the Executive Board for two years, as an ordinary member, and had at the same time represented it as an observer to the Professional Board. IFLA is so complicated that it is almost a necessity to have been on one of the administrative bodies to see what it is all about.

C: Would you like to be president now, as the 
structure of IFLA is changing and becoming more complex?

G: Yes. But since I know IFLA from the inside now. that may be not a fair question. Because now I know that, through hard work, I might do an acceptable job, and also that I would have the privilege of meeting many interesting people. It was of course an advantage that I had already had close links with Unesco, representing the Nordic countries on the Council of the General Information Programme and being a member of the Norwegian Unesco Commission.

C: In the general context of the advancement of women into new roles, how do you feel in general about a woman being president of IFLA?

G: Based on the fact that Norway is an initiator in the work for the equal status of women in society and has a government with almost 50 percent of the ministers being women, I find it quite natural to have a woman president in IFLA, taking into account the number of female librarians. It has been a greater problem to explain at home what it implies in general to be president of such a big international

organization. In Norway we are very careful not to talk loud about our own success. Everybody must be equal and no one exceptional. 'You must not believe that you are something', has for too long been a prevailing slogan, stemming from a famous Norwegian novel. It has indeed been characteristic of the Norwegian attitude. Fortunately it now seems to be changing. It is again permissible to have ambitions and this change in attitude is really urgent if we are to enter the European Community.

Remembering Norwegian colleagues asking why I could not concentrate on doing a proper job at home, it gave me a certain satisfaction when some of those attending an IFLA conference for the first time this year expressed their surprise at the big and important event such a conference is and what a responsible task the presidency implies.

Talking about women in leading positions, I remember that many years ago when I was asked to the United States to speak in a seminar, to tell how it was to be a woman in a top position, 1 didn't really understand why, because it was quite natural to me. But I understood when I was there and listened to American people, American colleagues, female colleagues; and I talked about trade unions, I talked about everything, and lots of thıngs were new to them.

C. Were there any women that you know of in IFLA who wanted to come up but couldn't because of the old boy's club that IFLA was considered to be?

G: I don't know of any and I haven't really thought that way. But I had of course also heard that expression and must admit that was also one of

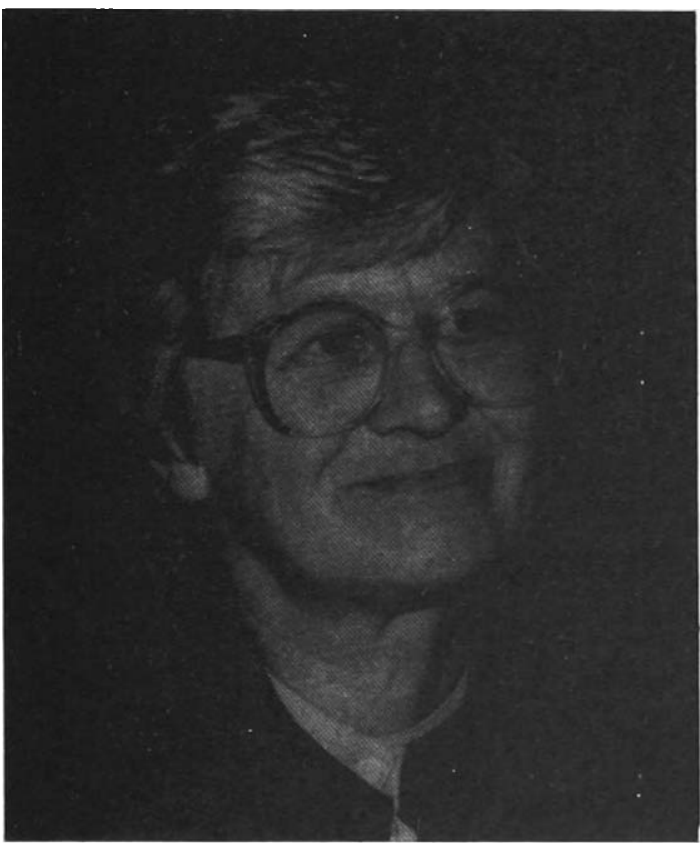

E/se Granheim

my reasons for accepting nomination. But even more oecause I was a public librarian. Yes, I felt it was about time that some other libraries began to play a prominent part in the club.

C: Public, as opposed to say, national librarians, in the club?

G: Yes, I mean any, public libraries, school libraries, all these grassroot services, so basic for further education.

C: The Russian vice-presidents of IFLA have always interested me. We nearly always had one over the last twenty-five years of IFLA. I don't know whether it was a rule of thumb of IFLA that we should try to have them.

G: Not as far as 1 know. Their names were put forward from the Soviet authorities and show indeed that women have reached far in the USSR. I knew some of them very well. Marguerite Roudomino had left IFLA when I took over, but we exchanged letters for many years. I am sorry that she died earlier this year, as she was very much looking forward to the IFLA conference in Moscow in 1991. Ljudmila Gvishiani-Kosygina was a most charming colleague, who due to her political influence was of great importance to IFLA. She was extremely good at finding workable compromises so that the ground for cooperation between East and West could be the best possible. She eased my working situation very much. When none of these outstanding persons advanced to the top of the ladder it might just be due to a coincidence, but more likely to political considerations. 
As far as I am concerned, 1 am aware that being a woman at the right time and coming from Norway, a small country, were helpful in getting elected. Norway is not neutral, but it is not dangerous; we have links to all sides. Earlier, it was more difficult for candidates coming from the greater countries, for instance, the Soviet Union and the United States, to get enough support to become the president. Although IFLA is a totally professional organization, we cannot hide the fact that the country of origin of a candidate has some significance. Norway has gone to great lengths to assist the developing countries. We give a lot of development aid; we have also good contacts, too, for instance with the Soviet Union. I am happy to say that, in my work in IFLA, I was a contact between West and East and especially with the developing world, for which I am very grateful.

C: Are there any women now in IFLA in high positions who are doing good work, who are going to be more important?

G: I think there are. I think there are such people, although they may be still somewhat reluctant, as they have not yet spent long enough inside the steering bodies of IFLA; and the structure of IFLA is quite different from what you are familiar with in national or regional library organizations.

C: You were elected in Copenhagen in 1979, and 1 thought you might enlarge here on things you thought important enough to include in your address at the official opening of the IFLA conference in Munich in 1983, and I quote you:

I am firmly convinced that there is an increasing interest in IFLA in Latin America and hope that currency problems and other economic difficulties will not create obstacles to extend cooperation and a broader participation in IFLA's professional bodies.

Our welfare societies have, in all their efficiency, become more and more impersonal. We contribute to all kinds of welfare by paying our taxes or by contributing voluntarily to different agencies which disburse the funds impersonally. We do contribute out of a spirit of fellowship, but we offer as a reason for the impersonal gesture the fact that we wish to avoid embarrassing others. We no longer feel a personal responsibility. I think we shall have to reconsider this view.

IFLA and all its members have an important task in convincing politicians that it is through knowledge and information that we are able to face depression and find effective remedial measures. This is true for the developing as well as for the industrialized areas of the world.
Librarians are still considered as a serious but all too modest occupational group. When the public becomes aware of services or new medias in the libraries that it has not known about, I have never found that the public blames its own ignorance. It is always the library which is blamed for lack of information. This is also one of the reasons why I am in full sympathy with the idea of 'An International Year of the Library'.

G: These quotations, seen against the IFLA of today, show that it has not stagnated since I left and that my working conditions at home have also changed. For quite a number of years after the Second World War, IFLA consisted primarily of librarians from European countries and North America. And so it became important to extend participation to other continents. I think I gave it a push when I went to Venezuela in 1982, although that was for Unesco. I was then able to go on to Brazil to meet colleagues and talk about IFLA in Rio and São Paulo. IFLA did not,

however, make good headway on that continent before Spanish became an official IFLA language in 1987 and my successor got the opportunity to visit a number of countries there.

Asian and African countries were already participating in IFLA, though on a more modest scale. There, there had not been the same language barriers as in Latin America. The majority of countries having members in IFLA now belong to the Third World; and they come with great demands and hopes of what IFLA can do. At the same time the fact that they pay less in dues, and I think that they should, means that IFLA does not have the money it needs to expand its activities according to the number of members. It has been necessary to get sponsors, cooperate closely with other organizations and unite forces.

I must admit that the work of getting sponsors was one of the very new things to me, coming from a so-called welfare society where it is the authorities' task to solve problems from public money. Then, on behalf of IFLA, to have to go out and ask for money, from development agencies and other relevant bodies around the world, was quite new to me. On the other hand, when you then succeed in getting money, you get a very good feeling.

When I said that also my working conditions at home had changed, I was thinking how familiar we too have become with sponsoring. The welfare society has in many ways unfortunately failed, but we have established a structure in society which makes it very difficult to get away from the impersonal attitude and take responsibility. I learnt a lot about that in IFLA.

C: Were you pleased with your accomplishments in relation to the changes in the structure of IFLA? 
G: Well, the changes in structure were first proposed at the 1975 conference in Oslo; they came to nothing just then and were approved in Lausanne the next year. The structure has often been called complicated, nonetheless, 1 think it works because it is in the sections that you find the professional work. And that is where you have to start, if you want to achieve something. There you get the practical questions and problems which you also deal with at home, and learn to see them in an international relief and solve them from that angle.

C: At this point then, there is no big structural change anticipated within IFLA; I mean, this one is working, with modifications?

G: No big structural changes as far as I know, but there is almost continuous consideration of the structure. When new people come in, they often bring forth the same questions which have been raised before. To an old IFLA fox like me, this is a bit amusing, but you have to go through this process and after all it shows interest in IFLA.

C: In Budapest in 1972, the meetings of IFLA and FID (International Federation for Information and Documentation/ were held back to back and later there were meetings to discuss cooperation between IFLA, FID, and ICA (International Council on Archives).

$\mathrm{G}$ : Yes, also during my term in office a number of meetings were held to discuss cooperation in common fields of interest and this natural cooperation goes on. Professional education and conservation of media are such areas. But I don't think a total amalgamation of the three organizations is of current interest.

C: The core programmes have grown in number. Is there anything important that IFLA needs to add?

G: Not apart from giving the ALP (Advancement of Librarianship in the Third World) programme a solid basis. On the other hand I think it is quite logical that UBC (Universal Bibliographic Control) and IM (International Marc) amalgamated. The one that was established in my term was UAP (Universal Availability of Publications). The name might be considered out of date when other materials, apart from printed publications, might be considered equally relevant for libraries; but as long as printed publications are so much less easily available in many Third World countries, I am glad that the UAP programme still concentrates on this, and I do think that printed material will never be outdated.

I am concerned about UAP now, having just attended the Pre-session Seminar for Developing Countries and heard about the lack of paper and lack of publications. We were talking about illiteracy and what libraries can do to improve literacy. The librarians say. 'Well, when we have only a few books, should literacy work be a

\section{IFLA}

Founded in 1927, the international Federation of Library Associations and Institutions (IFLA) is an independent international non-governmental association; its purposes are to promote global understanding, cooperation, discussion, research and development in all fields of library activity and information science, and to provide a body through which librerianship can be represented in matters of international interest. IFLA has Category A status with Unesco.

IFLA currently has 1,213 members (essociations and institutions) from 123 countries. It works through two types of bodies: Professional Groups (thirty-two Sections and eleven Round Tables organized into eight Divisions) and Core Programmes. Annual conferences are held in different countries.

\section{DIVISIONS}

1. General Research Libraries

2. Special Libraries

3. Libraries serving the General Public

4. Bibliographic Control

5. Collections and Services

6. Management and Technology

7. Education and Research

8. Regional Activities

\section{CORE PROGRAMMES}

1. Universal Avallability of Publications (UAP)

2. Univergal Bibliographlc Control International Marc (UBCIM)

3. Preservation and Conservation (PAC)

4. Universal Dataflow and Telecommunications (UDT)

5. Advancement of Llbrarianship in the Third World (ALP)

\section{IFLA HEADQUARTERS}

IFLA Headquarters is located in The Hague. Netherlands:

POB 95312, 2509 CH The Hague, Netherlands. Tel: +31 (70) 140884 . Telex: 34402. Fax: $+31(70) 834827$.

major task for us, or should we just be a link to other organizations and institutions that have the basic responsibility for literacy?"

I think we all agreed that librarians should not themselves teach; but they should take their place among other organizations and institutions 
and be a link between them for this purpose. Many libraries have great problems merely in getting books and printed material into the country. They cannot receive gifts because of tax. I think that UAP has a long way to go before we can say that it has succeeded, but it is an objective, as well as a programme.

What about the programme for the Advancement of Librarianship in the Third World (ALP)? 1 think ALP, the last core program, which was presented here in Stockholm, is also one which IFLA must have very much at heart in the future I am very glad that the Swedish Development Agency has financed the pilot project. Sometimes I feel a little bit sore because Margreet Wijnstroom, the then Secretary General of IFLA, and I worked very hard on this programme, and we tried here in the Nordic countries to get support together; but most of the development agencies in the Nordic countries were not positively interested in it Sweden, however, said yes. And so during this conference they had a lot of public relations for it. They deserve it. I think the other countries have not understood the importance of supporting such a programme.

What meeting was the best one during your tenure in office?

That is impossible to answer. I would say they were good in different ways. The criteria for a successful conference in Montreal might be different from those in Manila, depending not only on the expectations of the usual participants, but as much on the benefit the conference could bring to the local professionals. The secretariat on the other hand appreciates moving into well equipped of fices to run the conference efficiently. But that cannot be expected everywhere, in countries that are far from wealthy.

Two IFLA conferences have been held in Third World countries - the Philippines and Kenya. I was not able to attend either of them, unfortunately, but from colleagues I heard they were great meetings. These were people who have been to more than one IFLA, and they thought these conferences were the best

For political reasons, many people criticized us for going to the Philippines, but that is one thing I never regretted, because I have never in my life met so many grateful people, so many grateful colleagues. It was the first and only time for most of them to meet with colleagues from all over the world and to attend a lot of professional meetings. I remember the local organizers were almost in despair because the meeting rooms they had reserved based on ordinary attendances were all too small because of all of the local people coming in.

That is success I
G: Yes! Exactly! And Nairobi was also a success although there we suffered some practical problems in getting exhibition materials and so on into the country. But the problems are not the major impression of the conference to ordinary participants. In a way, these two conferences have meant the most to me as well. They have given me great opportunities to meet the people of those countries

C: Has IFLA been influenced by the wave of internationalism recently? Has it been because there is a bandwagon? Was it because of Unesco and the availability of money, or was it the activities required by the profession, the actual needs? Or is it the leadership that is coming either from countries or individuals?

G: It might be a combination of these things. But personally I have not felt it that way. From the part of the world I come from we have always felt it a must to be internationally informed. As far as the developing countries are concerned, it has of course something to do with their independence from the colonial powers and thereafter participation in Unesco.

Support from development agencies might also have pushed development. Some of these agencies have supported several IFLA projects during the last decades. IFLA has had to accept, however, that their priorities do not always correspond to its own. It might happen, for example, that you have a better chance of getting support for your third priority project rather than the one to which you would give first priority. You must listen to the policy of the sponsors.

Talking of international organizations of importance to IFLA as well as to the library world in the various countries directly. I'll first and foremost mention Unesco.

I told the participants in the Pre-session Seminar this year to go home, talk to those in their own country with influence in Unesco, and tell them about the library needs. You see, the Unesco General Information Programme, when dealt with at the Unesco General Conference, takes only a day and a half. Very few countries can send librarians to be present for such a short period and many are represented by permanent delegates to Unesco, or members of Unesco national commissions who have to cover different sessions.

When Unesco's General Conference took place last year, it was then just two months before International Literacy Year started, but those who attended were mainly talking about management, technology, training, networks-important enough, but what it all should be used for - that did not occur. And that's also because books and media are dealt with in the Unesco cultural programmes and not when the 
General Information Programme is being discussed. There are still too watertight compartments, I feel. Therefore, I told the participants in the Pre-session Seminar to inform more at home, try to do some lobbying, and tell the representatives to Unesco conferences what libraries are about, what should be achieved, and first and foremost, what is needed to help illiterates become literates.

C: Is this then the influence of a kind of international bandwagon?

G: No, no, I don't think so; but IFLA's representatives must listen to the grassroots because those people come with their experiences, they come with their practical needs, and they know what's going on right now: cuts in budgets, attacks on the right to borrow library materials free of charge, and so on. In all these issues IFLA must always be in the forefront. In order to do so they must listen to what is going on in the sections, where the grassroots are represented.

C: Was there a time when you realized that you personally were an internationalist and is it an attribute of leadership?

G: As I said, right from the beginning my curiosity... and also it's been a necessity for me. When you have a top position in a national context, then in order to get ideas and contacts. you must get abroad.

C: Has anyone to your knowledge studied IFLA as an international organization?

G: I must say I cannot think of anything of that nature if you mean serious research. But I would say that IFLA has constantly achieved higher esteem. Unesco now has to rely more on nongovernmental organizations (NGOs) and I think IFLA has a very important part to play. In the different NGOs you find the experts, so I think that is a sound and natural development.

C: Do you think IFLA itelf has paid attention to the literature of internationalism or to some other international organizations as a pattern for IFLA. say in structure more than anything?

G: I assume those working on the statutes in 1975-76 were familiar with the structure of other organizations, although I don't know if they followed any specific pattern.

C: Let's look to the future now with the realization of needs, trends, and theory that exist for international librarianship.

G: You need a forum for specialization on the one hand-exactly what IFLA has in some sections. But on the other hand, from the national point of view, I think you need, more than ever, cooperation, cross-sectional cooperation. We have had great cuts in budgets, and in the first few years we protested eagerly. Now, we have reached the stage where we accept that we won't have more money. This is a challenge. We must now show new initiatives to get more and new things out of the same amount of money, and in a manner so that libraries will reach new user groups.

Libraries must try to get more legs to stand on and in that way get more supporters among politicians. In order to reach that goal, crosssectoral cooperation is absolutely essential. For example, we must put branches for elderly people into old people's homes, and in this way cooperate closely with social workers. We must combine branches for children with school libraries, in short get more contact with the outside world, with other sectors, with other professions.

The world is different now. The majority of people, at least in my country, now prefer a bigger library with better staff, better book stock, longer opening hours. Ten years, ago, they said they wanted a small, nice little library in their local environment. Now they have greater demands. You have constantly to adapt yourself to changes in society. I don't think maybe libraries have been clever enough in that way. No library is similar to another. No two libraries have the same users. Library service must not be, how you call it, petrified. And that is a great challenge to IFLA, too.

C: IFLA's Universal Dataflow and Telecommuni cations (UDT) programme aims to promote the flow of information across national borders, and so involves IFLA in trying to influence national policy in this respect. This seems to be different from the influence IFLA has traditionally exerted through people attending IFLA meetings and sharing information.

$\mathrm{G}$ : Yes, that is correct, but that must not prevent IFLA to work for a change of national laws if they seem to hamper a natural development. Why do we work for compatible systems if it is not to communicate also across national borders? IFLA has to be a spearhead in this work and I see UDT as a useful programme in this context.

C: So you agree that information should flow over borders without hindrance - that the transfer of information is the important matter?

$G$ : I think we must not forget that we work in an international profession; our work is of an international character. Some years ago, before glasnost, I was a Norwegian delegate to a conference on peace and freedom in Europe, where cultural issues were on the agenda. Most branches of science and knowledge were represented and also a number of librarians with the gift of speech. I felt that many in the audience were not used to librarians playing an active part in the discussion like we did and expressed some irritation. The answer given by a British librarian l'll keep in mind for ever: 'Can't you see that we librarians are building the 
bridges for you to walk on?' Libraries are links between all countries so that scientists, researchers, educationalists, everybody can get the information they need.

$\therefore$ Sometimes IFLA does not have as much power to influence events as some people would like it to have. IFLA may believe that something should be done, but it cannot move fast enough. Is there no way that IFLA can say to a country, you should do...

i: You must remember that is an NGO. Besides, we must accept that international work is always slow; it takes time to make decisions and move forwards, and we have to accept that right from the beginning. Trying to make all the different countries cooperate and agree, why should it be any easier for us than for other international organizations? Although IFLA can influence, input, inspire, the country itself must always decide its own library policy, and the local community its own library policy; but the local policy must fit into the national one and the national policy into the international one.

;: Now I will stun you, perhaps, with some terms from a recent book on international organizational change. Was there any time in IFLA when you felt that IFLA actions could be described by these terms:

incremental growth, unanimity, qualified majority, turbulent non-growth, simple majority leading to consensus, managea interdependence, consensus.

3. That is not so easy to answer. I must speak to the purposes of IFLA; it is an independent professional organization which aims to promote international understanding in addition to development in all fields of librarianship. From time to time there has, of course, been some turbulence due to different political views, but it has mostly been possible to solve difficult questions inside the four walls of a meeting room. When such problems are presented to you, you must first find out why the difference of opinion exists, and start working on solutions from there. Not exactly bargaining, more diplomacy.

$\because:$ Managed interdependence?

3: Yes, but I want to add: why should it be any easier to manage an international organization than a national one? In national professional organizations it is not always only the professional aspects that count either. When you represent a group, a district or even a country, you must be prepared to answer for your statements and contributions when you get back home. In the IFLA context, we had to accept that, and try to find solutions which were acceptable to the various interests involved, but which at the same time did not make IFLA suffer. Very often, only a few words in a text can make a lot of difference...

C: Is there anything you want to say that I haven't mentioned?

G: No, I am grateful for IFLA. Because of the people, and for the challenges it gave me.

C: Any advice for the future?

G: Not to those managing IFLA today. Development goes so fast, and I see clearly that if you have been outside for only a few years, you should be very careful in giving advice. If you have just kept in touch all the time, have read about what is going on and discussed it with people, which I have been trying to do, then you may give some advice, but in private, not officially.

C: Will you go to the IFLA meeting in Moscow next year?

G: I'm not sure at the moment. Now, when I have no commitments officially within IFLA, I have gone back to more Nordic commitment; I am chairing a working group for the Nordic ministers on public library cooperation and next year I will be in charge of a seminar for librarians from South European countries belonging to the European Community. I am also back on the Norwegian National Commission to Unesco.

C: Perhaps we will meet next year at IFLA. Thank you for these words.

\section{Reference}

1. Haas, Ernst, B. When knowledge is power, three models of change in internationalorganizations. University of California Press, 1990, p. 92

\section{Abstract \\ Edited text of an interview with Else Granheim, Director General, Statens Bibliotektilsyn (Norwegian Directorate for Public and School Libraries), Oslo, and former President of the International Federation of Library Associations and Institutions (IFLA). The role of president of IFLA is discussed from the point of view of $a$ woman, the only one who has held the office. Also, the structure and problems of IFLA are discussed.}

Frances Laverne Carroll is Professor Emeritus at the School of Library and Information Service. University of Oklahoma, Norman, USA. 